\section{Stiles-House 則}

アルドール化合物の threo/erythro 相対立体化学を ${ }^{1} \mathrm{H}$ NMR スペクトルにおける $\mathrm{H}^{\alpha}$ と $\mathrm{H}^{\beta}$ 間の結合定数の 大小関係から推定する経験則を Stiles-House 則という。

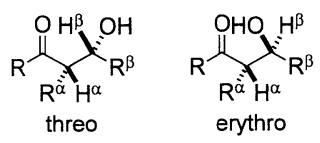

Stiles らは, 分子内水素結合による 6 員環構造を形成 した場合, threo 体では $\mathrm{H}^{\alpha}$ と $\mathrm{H}^{\beta}$ の関係が, $10 \mathrm{~Hz}$ 程度 の大きな結合定数值を与える antiperiplanar，および 2 $\mathrm{Hz}$ 程度の小さな值を与える synclinal となる 2 つの配座 が可能であるのに対し, erythro 体では可能な 2 つの配 座において $\mathrm{H}^{\alpha}$ と $\mathrm{H}^{\beta}$ がいずれも synclinal となることか ら, erythro 体に比べて threo 体の結合定数值が大きく なることを解析結果に基づいて示した。その後 House らが，分子内水素結合による椅子型 6 員環構造を仮定し て，その配座安定性をもとにした相対立体化学決定法へ と拡張した。この方法は簡便であるため多くの交差型ア ルドール反応の生成物の立体化学の推定に利用された。 しかし, 結合定数の大小関係が逆転する例が多数報告さ れるとともに, House らの仮定に無理があることも示さ れており，安易に利用することは避けなければならない。

(中野啓二, 北村雅人)

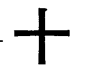

\section{メバロン酸経路と非メバロン酸経路}

テルペノイドやステロイドをはじめとするイソプレノ イドは, メバロン酸を中間体としこれからイソペンテニ ル二リン酸(IPP) を経て生成する (メバロン酸経路) とい うことは，今日の生物 (有機) 化学の教科書で必ず触れら れている。一方, 1993 年 Rohmer らは, バクテリアの ホパノイド生合成過程では, IPPがメバロン酸経路によ らない新たな経路で生成することを提案した。その後 Rohmer，瀬戸-葛山， Eisenreich-Arigoni を代表とする 多くの研究者の解析により, グリセルアルデヒド-3-リ ン酸とピルビン酸が原料となり 1-デオキシ-D-キシル ロース 5-リン酸が生成し, 次いで炭素骨格が転位した 2-C-メチル-D-エリスリトール 4-リン酸 (MEP)を経て IPPに変換される系の存在が明らかとなった。これを非 メバロン酸経路 (mevalonate-independent pathway, non-mevalonate pathway, MEP pathway) と呼ぶ。非メ バロン酸経路は微生物, 植物に広く分布する。植物では 細胞質中のステロイドはメバロン酸経路で生成するが, 葉緑体内のカロチノイドやフィトールをはじめギンコラ イドやタキソールの骨格は非メバロン酸経路で生成する ことが示されている。

(山内敬明)

\section{プロセス化学}

一ロにプロセス化学と言っても, その解釈は千差万別 で明確な定義は難しい。開発後期の化学工学領域や GMP などの規制が脳裏に浮かぶ人や，もう少し狭義に 解釈する人もいる。時代の流れに伴うビジネスニーズの 変化に応じて, 医薬開発やその製造プロセス開発の過程 も変化する。しかし, 医薬品が人類の病苦からの解放を 担う限り, プロセス化学の役割は迅速な研究開発のサ ポートと高品質な原薬を安価に安定供給することであ る。さらには地球規模での環境保全を考慮したグリーン の概念も反映しなければならない。このように大きな目 的を達成するには, 究極的な効率化, 生産性の向上が不 可欠であり，極めて高度な合成プロセスを考案し，実現 する必要がある。これが合成化学を中心とした産学連携 を重要視する理由である。最近の動向として, 開発初期 では,さらなるスピードアップを目指した基礎研究段階 からのプロセス化学の関与, アウトソーシングの利用を 含めたプロセス開発への効果的な投資, 開発後期におけ るパイロットプラントの有効利用と実製造設備への慎重 な投資などが叫ばれている。いずれにしろ化学と銘打つ 学問領域であるからには，プロセス化学の本質は有機化 学や合成化学が基軸であり, 有機合成化学の発展がプロ セス化学の発展を担っている。

(伊藤孝浩)

\section{路}

\section{タンパクの翻訳後修飾}

タンパクは, DNA から RNAへの転写, RNA からの 翻訳を受けて生合成されるが，その後にも様々な修飾を 受けており，これを翻訳後修飾と呼んでいる。これによ りほとんどのタンパクの細胞内外以の輸送や，安定性な どが制御されているだけでなく，翻訳後修飾を受けるこ とで初めて本来の機能が発揮される場合も多い。つま り，翻訳後修飾とはタンパクの機能を動的に制御するた めの，いわばスイッチのような役割を果たしている。そ の修飾様式には, タンパクの切断 (プロセシング)や化学 修飾があり，化学修飾には，リン酸化，糖鎖の付加が有 名であるが，その他にもメチル化，ヒドロキシル化，硫 酸化, ユビキチン化, イソプレニル化, 脂肪酸の付加な ど現在までに 300 種類以上の多くの修飾様式が確認され ている。これらタンパク全体から見ればほんの小さな修 飾が, 親水性や，3次元構造を変化させているのだが, その役割や機能については不明な点も多く, 修飾様式す ら確定していないものも存在する。近年, 分析機器など の発達により，続々と新たに重要な役割が解明されてお り，また，その修飾酵素を薬剤分子標的として新規医薬 品開発への応用も盛んに行われている。

(岡田正弘) 